\title{
Notes
}

\section{The benzoylarginine peptidase from Treponema denticola (strain ASLM), a human oral spirochaete: evidence for active-site carboxyl groups}

\author{
K. K. Mäkinen,* C.-Y. Chen, P.-L. Mäkinen, K. Ohta \\ and W. J. Loesche \\ Department of Oral Biology, School of Dentistry, The \\ University of Michigan, Ann Arbor, Michigan 48109, \\ USA.
}

\section{Summary}

The benzoylarginine peptidase of Treponema denticola (strain ASLM; a human oral spirochaete) was progressively and irreversibly inactivated by 1-(ethoxycarbonyl)-2-ethoxy-1, 2-dihydroquinoline, a carboxyl-group reagent. At acidic $\mathrm{pH}$ values, reaction of one mole of the modifier per active site of the enzyme resulted in total inactivation of the enzyme. Assuming that this modifier is a specific carboxyl reagent, the data suggest that the inactivation of the $T$. denticola benzoylarginine peptidase was caused by the modification of one carboxyl group located close to the active site of the enzyme. Results obtained with Woodward's reagent $\mathrm{K}$ ( $\mathrm{N}$-ethyl-5-phenylisoxazolium 3 '-sulphonate) supported these findings. Carbethoxylation with diethylpyrocarbonate effectively inactivated the enzyme, and addition of hydroxylamine at $\mathrm{pH}$ 7.0 restored the activity almost totally, suggesting that the pyrocarbonate had reacted with tyrosyl or histidyl residues.

\section{Introduction}

Spirochaetes are helical, motile bacteria, many of which are found associated with a large number of eukaryotic hosts, from protozoa to mammals (Canale-Parola, 1977; Hardwood and Canale-Parola, 1984). One of the spirochaete genera, Treponema, is present in the mouth, intestinal tract, and genital areas of humans and other animals (Canale-Parola, 1977). The human oral spirochaetes have been associated with various types of periodontal disease (Listgarten, 1976; Listgarten and

Received 2 December, 1989; revised 5 April, 1990 . *For correspondence. Tel. (313) 936 2600; Fax (313) 7473896.
Hellden, 1978; Loesche et al., 1982, 1985), the development of which may depend partly on the activity of proteolytic enzymes from these organisms. A previous paper (Ohta et al., 1986) reported the purification and partial characterization of a benzoylarginine peptidase from Treponema denticola (strain ASLM) (implying that the enzyme was discovered in terms of its high activity on $N \alpha$-benzoyl-L-arginyl-p-nitroaniline (BAPNA) and $N \alpha$ benzoyl-L-arginyl-2-naphthylamine (BANA). This enzyme is a $50-65 \mathrm{kD}$ heat-labile protein which has no activity on casein, haemoglobin, azocasein, azocoll, serum albumin and gelatin (Ohta et al., 1986). It is possible that the enzyme plays a role in the nutrition of the spirochaetes.

Because $T$. denticola is pathogenic to man, it can be assumed that the proteolytic enzymes produced by this organism play an important role in the inflammatory reactions where the presence of $T$. denticola has been demonstrated. In spite of the previous advances (CanaleParola, 1977; Hardwood and Canale-Parola, 1984) in the study of the physiology and morphology of these organisms, very little is known about their proteolytic enzymes. The purpose of this paper is to summarize our detailed experiments, which suggest the involvement of a carboxyl group in the activity of $T$. denticola benzoylarginine peptidase. The importance of this group was studied using 1-(ethoxycarbonyl)-2-ethoxy-1, 2-dihydroquinoline $(E E D Q)$ as the principal modifying agent. This reagent has been found to modify essential carboxyl groups in enzymes and it has been claimed that it is highly specific for the activation and modification of such groups ( $\mathrm{Ho}$ and Wang, 1980; Ting and Wang, 1980; Pougeois et al., 1978; Saccomani et al., 1981; Phelps and Hafeti, 1984; Mäkinen and Mäkinen, 1987).

\section{Results and Discussion}

\section{Effect of EEDQ}

Inactivation of the benzoylarginine peptidase by EEDQ at $40^{\circ} \mathrm{C}$ was determined in $0.05 \mathrm{M} 2$-(morpholine)-ethanesulphonic acid monohydrate (Mes) or $0.088 \mathrm{M}$ phosphate buffers (at $\mathrm{pH}$ values ranging from $5.4-6.6$, i.e. with a range 


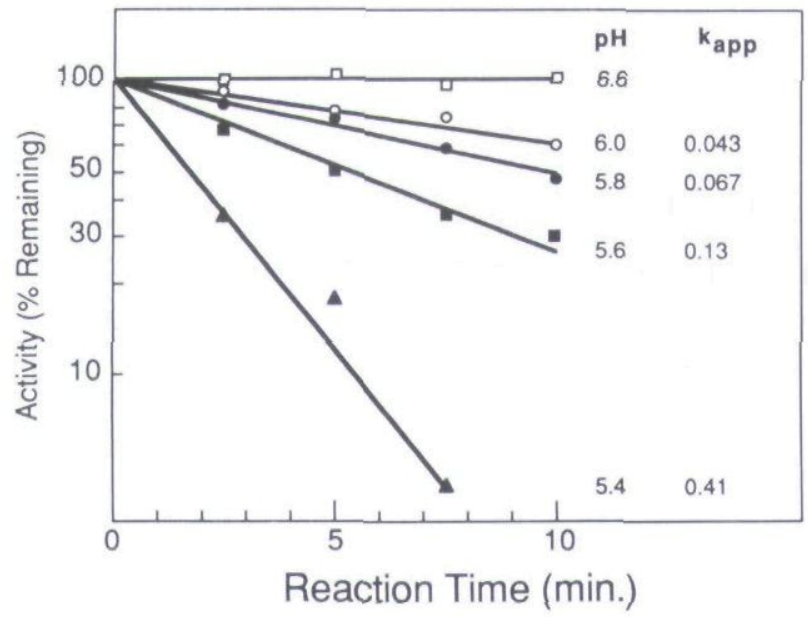

Fig. 1. Dependence of the rate of the EEDQ-caused inactivation of the $T$. denticola benzoylarginine peptidase on $\mathrm{pH}$. The modifications were carried out in $88 \mathrm{mM}$ phosphate buffers at $40^{\circ} \mathrm{C}$. The $\mathrm{pH}$ values of the modification mixtures and the values of the apparent rate constants of inactivation $\left(\mathrm{min}^{-1}\right)$ are indicated.

of $\mathrm{pHs}$ at which the enzyme was sufficiently stable at $40^{\circ} \mathrm{C}$ ). Figure 1 shows that the inactivation of the enzyme was clearly $\mathrm{pH}$-dependent: the rate of inactivation increased with decreasing $\mathrm{pH}$ (compared with stability controls included at each $\mathrm{pH}$ values). EEDQ had no effect at $\mathrm{pH}$ 6.6., whereas at $\mathrm{pH} 5.4$ the enzyme was totally inactivated in $7-10 \mathrm{~min}$. Figure $2 \mathrm{~A}$ shows that at $40^{\circ} \mathrm{C}$, $0.45 \mathrm{mM} E E D Q$ in $0.088 \mathrm{M}$ phosphate buffer $(\mathrm{pH} \mathrm{5.8)}$, caused an almost $90 \%$ inactivation in $7.5 \mathrm{~min} ; 2.0 \mathrm{mM}$ reagent inactivated the enzyme totally in 2-3 min (not shown). The secondary plot of $\log \left(1 / \mathrm{t}_{0.5}\right)$ versus $\log$ [EEDQ] produced a straight line with a slope of 0.99 , suggesting that the observed rate of inactivation was dependent on [EEDQ] to the first power (Fig. 2B). This kinetic plotting method has been used to calculate the number of inhibitor molecules able to react per active site of an enzyme (Pougeois et al., 1978; Phelps and Hafeti, 1984). Thus these results suggest that EEDQ has reacted with a reactive residue that is essential to the activity of the enzyme and that reaction of one mole of EEDQ per active site of benzoylarginine peptidase had probably caused this total enzyme inactivation. Collectively, these data showed that the inactivation of the enzyme by EEDQ was time-, concentration-, and $\mathrm{pH}$-dependent. In previous studies (Pougeois et al., 1978; Saccomani et al., 1981; Phelps and Hafeti, 1984; Mäkinen and Mäkinen, 1987; Mäkinen et al., 1982) such kinetic behaviour has been interpreted in terms of EEDQ reacting with an active carboxyl residue. The presence of BAPNA or BANA protected against the EEDQ-induced inactivation by $50-85 \%$ (both substrates were used at 5-25 mM concentrations).

\section{Effect of Woodward's reagent K (WRK)}

The effect of WRK on the activity of the enzyme was timeand concentration-dependent. The routine experiments were carried out in $0.1 \mathrm{M}$ phosphate buffer, $\mathrm{pH}$ 5.8. Under these conditions, WRK (initial concentration $4.9 \mathrm{mM}$ ) destroyed more than $80 \%$ of the enzyme activity in $60 \mathrm{~min}$ $\left(22^{\circ} \mathrm{C}\right)$ (not shown), while $1.5 \mathrm{mM}$ WRK caused a $10 \%$ inactivation in the same time. The above substrates $(5 \mathrm{mM})$ protected inactivation by WRK by $75 \%$. The effect of WRK was also studied in different acidic $\mathrm{pH}$ values in $0.2 \mathrm{M}$ Mes as described earlier (Mäkinen and Mäkinen, 1987; Mäkinen et al., 1982). The inactivation rate increased with increasing $\mathrm{pH}$ of the modification medium, suggesting that WRK reacted with the deprotonated form of an enzyme carboxyl group. It has been claimed that WRK is a specific carboxyl-group reagent when tested under the conditions described above (Mäkinen and Mäkinen, 1987; Mäkinen et al. 1982).

\section{Effect of 1-ethyl-3-(3-dimethyl-aminopropyl) carbodiimide hydrochloride (EDC)}

The inactivation of the enzyme by EDC was studied in the presence of a nucleophile (glycine methyl ester) and

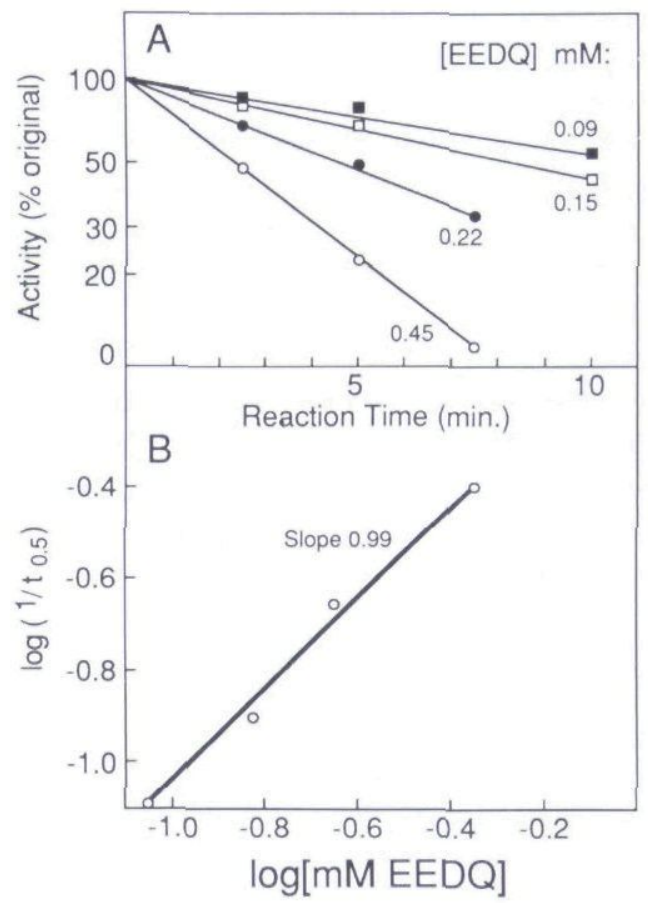

Fig. 2. Modification of the T. denticola benzoylarginine peptidase with EEDQ.

Panel A. Time course of inactivation of the enzyme. The enzyme (about $0.5 \mu \mathrm{M}$ ) was treated with EEDQ in $88 \mathrm{mM}$ phosphate buffer, $\mathrm{pH} 5.8$. The EEDQ concentrations present in the modification mixture are shown. Panel B. Secondary plot of $\log \left(1 / t_{0.5}\right)$ versus $\log [E E D Q]$. The slope of the resulting curve is indicated. All modifications were performed at $40^{\circ} \mathrm{C}$. 


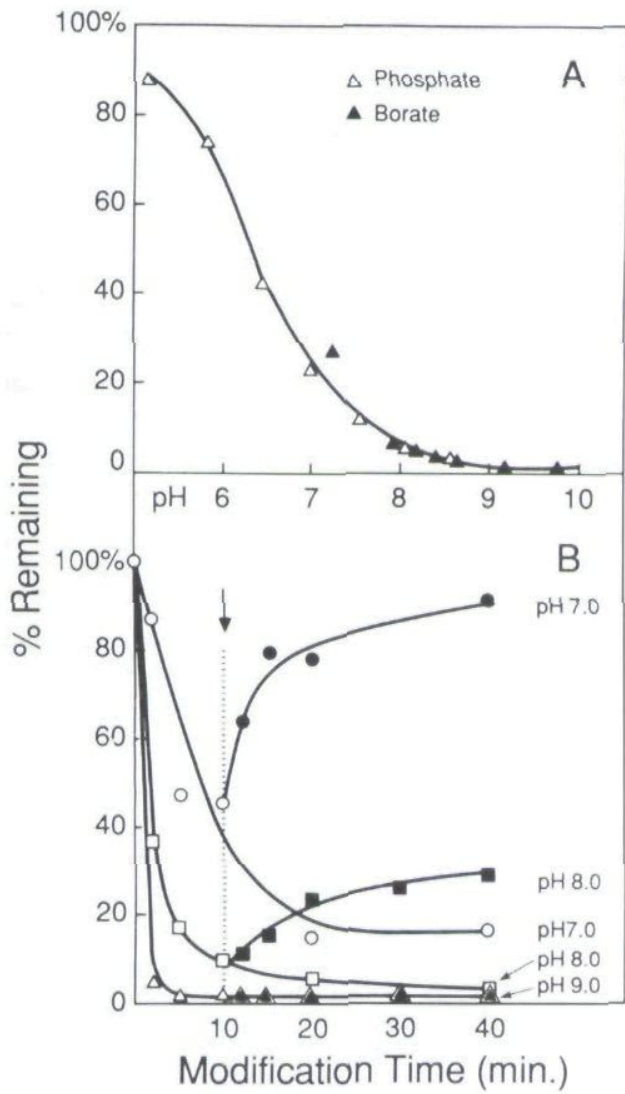

Fig. 3. Modification of the T. denticola benzoylarginine peptidase with DEP.

Panel A. Dependence of inactivation on $\mathrm{pH}$, tested in $50 \mathrm{mM}$ phosphate buffers or $50 \mathrm{mM}$ borate buffers.

Panel B. Inactivation of the enzyme with DEP (open symbols) and reactivation of the inactivated enzyme with $0.1 \mathrm{M}$ hydroxylamine (solid symbols). The inactivations were carried out either in $50 \mathrm{mM}$ phosphate buffers ( $\mathrm{pH} 7.0$ and 8.0) or in $50 \mathrm{mM}$ borate buffer $(\mathrm{pH} 9.0)$. The arrow at $10 \mathrm{~min}$ shows the addition of hydroxylamine.

without added nucleophile under conditions described elsewhere (Mäkinen et al., 1982). 10mM EDC inactivated the enzyme in a time-, concentration-, and $\mathrm{pH}$-dependent manner, but the inactivation proceeded at a rate approximately one tenth of the rate observed with EEDQ. The presence of the nucleophile was necessary for this inactivation, and $5-25 \mathrm{mM}$ substrates protected the enzyme against inactivation, as shown for EEDQ. Although EDC is less specific than EEDQ and WRK, the pattern of enzyme inactivation favours the possibility that this reagent may have reacted with a reactive carboxyl group. An aminopeptidase from Aeromonas proteolytica (Mäkinen et al. 1982) was shown to have an active carboxyl group and the inactivation of this enzyme by EDC was very similar to that of the benzoylarginine peptidase of $T$. denticola.

\section{Effect of other reagents}

The enzyme was treated at $22^{\circ} \mathrm{C}$ for up to $50 \mathrm{~min}$ with
0.1-5.0 mM concentrations of diethylpyrocarbonate (Mäkinen et al., 1982; Mäkinen and Mäkinen, 1987; Miles, 1977). These modifier levels (the molar ratio of modifier to enzyme was 100:1) caused a fast time- and concentration-dependent inactivation of the enzyme (Fig. 3). The secondary plots of percent activity remaining versus modification time indicated the involvement of two or more consecutive (or simultaneous) carbethoxylation processes. Virtually no inactivation was observed at $\mathrm{pH}$ 5.0 , whereas the process continued rapidly to an almost complete loss of enzyme activity at pH 8.5-9.0. The activity of the inactivated enzyme could be almost totally restored at $\mathrm{pH} 7.0$ by the addition of $0.1 \mathrm{M}$ hydroxylamine. It is possible that these results indicate the involvement of tyrosyl or histidyl residues in enzyme activity. Tetranitromethane, tested as described previously (Mäkinen et al., 1982; Mäkinen and Mäkinen, 1987) caused a rapid inactivation of the enzyme. None of the diketones or ketone aldehydes (2,3-butanedione, 1,2-cyclohexanedione, phenylglyoxal, glyoxal and 2,3-pentanedione) inactivated the enzyme under non-photo-oxidative (Mäkinen et al., 1982) conditions, suggesting that arginine residues may not be important for enzyme activity. Previous studies (Ohta et al., 1986) showed that the activity of the benzoylarginine peptidase did not depend on $\mathrm{SH}$ groups. The previous results (Ohta et al., 1986), suggesting that the enzyme is not inhibited by metal chelators but is inactivated by diisopropylfluorophosphate, were verified.

\section{Conclusions}

The fact that the $T$. denticola benzoylarginine peptidase was progressively and irreversibly inactivated by selective carboxyl group reagents, EEDQ and Woodward's reagent $\mathrm{K}$, should substantiate the presence of a reactive carboxyl group in this enzyme. With both modifiers the $\mathrm{pH}$ of the modification medium had a remarkable effect on the inactivation rate, which was more pronounced at acidic $\mathrm{pH}$ values. This was to be expected since a protonated carboxyl group is necessary for the reactivity of EEDQ (Pougeosis et al., 1978; Phelps and Hafeti, 1984). The behaviour of the acidic portion of the rate versus $\mathrm{pH}$ curve (Ohta et al., 1986) of the hydrolysis of BAPNA is in agreement with a reactive carboxyl group residue being present at or near the active site.

Although the inactivation of the enzyme upon treatment with EEDQ, WRK and EDC indicated the presence of carboxylate groups at the catalytic site, there is always the possibility of a side reaction or a conformational change indirectly altering the active site, or the accessibility of the reagent to the active site. Interpretation of protein-modification studies in general should consider this possibility; 
such studies should ideally be accompanied by the use of different labelling techniques and immunologic structural probes (Ludwig et al., 1985). EEDQ may cause the formation of inter- and intramolecular amide bonds (Saccomani et al., 1981), leading to intramolecular crosslinking (Phelps and Hatefi, 1984; Ting and Wang, 1980). Also, treatment of an enzyme with diimides may result in cross-linking of the enzyme protein (Phelps and Hatefi, 1984; Pougeois et al., 1978). Therefore the carboxyl reagents employed in this study may have triggered such long-range conformational changes. It is improbable, however, that three unrelated labelling reactions (using EEDQ, WRK, and EDC) could have induced the same extent of long-range changes. Furthermore, the protein amino groups are not reactive at those low $\mathrm{pH}$ values at which the inactivation of the enzyme by EEDQ was most rapid. This lessens the occurrence of EEDQ-induced cross-linking between those groups. Consequently, considering all the supportive information presented in this study, it is very likely that EEDQ and WRK (and possibly EDC) had reacted with a carboxyl group located near the active site, or at the active site, of the T. denticola benzoylarginine peptidase.

The present evidence suggests that diethylpyrocarbonate may have reacted with either histidyl or tyrosyl residues which are important to enzyme activity. The inactivation was most rapid at alkaline $\mathrm{pH}$ values, indicating that lysyl, tyrosyl or histidyl residues may have reacted with the modifier. However, the reaction was reversed at neutral $\mathrm{pH}$ values by hydroxylamine, which removes the carbethoxy group from modified hystidyl or tyrosyl residues but does not remove that group from modified lysyl or cysteine residues (Melchior and Fahrney, 1970). Therefore, cysteine and lysine may be ruled out as essential amino acid residues reacting with diethylpyrocarbonate.

There has been no comprehensive chemical study of any Treponema peptidase. The spirochaetes have been difficult to cultivate and this fact has been particularly true for oral treponemes, which display strict nutritional requirements. The present communication represents the first effort to elucidate the nature of the active amino acid residues of a spirochaete enzyme. Provided that EEDQ and Woodward's reagent $K$ can be regarded as specific carboxyl-group reagents, it appears that the activity of the $T$. denticola benzoylarginine peptidase depends on the reactivity of at least one such acidic group. In the classification of Neurath (Neurath et al., 1967; Neurath, $1984,1985)$ peptidases that are sensitive to diisopropylfluorophosphate and whose activities depend on an active carboxyl group are designated as serine proteases I (EC 3.4.21): this includes trypsin, with which the $T$. denticola enzyme shares some substrate-specificity characteristics (Ohta et al., 1986).

\section{Experimental procedures}

$E E D Q, E D C$, and Woodward's reagent $K$ were purchased from Serva. Other reagents were obtained from Sigma. The T. denticola benzoylarginine peptidase was purified as previously described (Ohta et al., 1986).

Enzyme activity was determined as previously described (Onta et al., 1986) at $30^{\circ} \mathrm{C}$ in assay mixture consisting of $0.3 \mathrm{ml}$ of $0.1 \mathrm{M}$ Tris- $\mathrm{HCl}(\mathrm{pH} 7.8), 0.1 \mathrm{ml}$ of $1.0 \mathrm{mM}$ BAPNA (or BANA) solution, $0.1 \mathrm{ml}$ of water and $0.1 \mathrm{ml}$ of enzyme (diluted with buffer). Protein was determined according to the Bradford method (Whitaker and Granum, 1980).

Chemical modification of the enzyme with EEDQ and EDC was carried out in mixtures consisting of $1.0 \mathrm{ml}$ of $0.05 \mathrm{M}$ Mes (normally $\mathrm{pH} 5.5$ ) or $0.088 \mathrm{M}$ phosphate buffers (normally $\mathrm{pH} 5.8$ ), and of $10 \mu \mathrm{g}$ of enzyme. After 5 min standing at $30^{\circ} \mathrm{C}$ (EDC and WRK) or at $40^{\circ} \mathrm{C}$ (EEDQ), various amounts of methanolic EEDQ (the final methanol concentration in stock solution was $10-50 \%$ ), or aqueous EDC were added to the modification mixture. The modifier solutions were freshly prepared. The extent of modification was followed at $30^{\circ} \mathrm{C}$ (EDC, WRK), or at $40^{\circ} \mathrm{C}$ (EEDQ) during periods of $30-120 \mathrm{~min}$ with small $(10-20 \mu l)$ aliquots withdrawn from the mixtures at the proper time intervals. Appropriate methanol and $\mathrm{pH}$ controls were included. Otherwise, the recommendations of the literature ( $\mathrm{Ho}$ and Wang, 1980; Ting and Wang, 1980; Pougeois et al., 1978) were followed. The treatment of the enzyme with EEDQ was carried out at $40^{\circ} \mathrm{C}$ to ensure complete dissolution of the reagent at higher concentrations. In protection experiments, the protectors were added to buffered enzyme $5 \mathrm{~min}$ before the addition of the modifier. Inactivation of the enzyme with WRK was carried out as previously described (Saccomani et al., 1981; Mäkinen and Mäkinen, 1987). The experiments with diethylpyrocarbonate (DEC) were performed as recommended by Miles (1977).

\section{References}

Canale-Parola, E. (1977) Physiology and evolution of spirochetes. Bacteriol Rev 41: 181-204.

Hardwood, C.S., and Canale-Parola, E. (1984) Etiology of spirochetes. Annu Rev Microbiol 38: 161-192.

Ho, Y., and Wang, J.H. (1980) Effect of hydrophobic carboxyl reagents on the proton flux through coupling factor $\mathrm{CF}_{\mathrm{O}}$ in thakyloid membrane. Biochemistry 19: 2650-2655.

Listgarten, M.A. (1976) Structure of the microbial flora associated with periodontal health and disease in man: a light and electron microscopic study. J Periodontol 47: 1-18.

Listgarten, M.A., and Hellden, L. (1978) Relative distribution of bacteria at clinically healthy and periodontally diseased sites in humans. J Clin Periodontol 5: 115-132.

Loesche, W.J., and Laughon, B.E. (1982) Role of spirochetes in periodontal disease. In Host-parasite Interactions in Periodontal Diseases. Genco, R.J., and Mergenhagen, S.E. (eds). Washington D.C.: American Society for Microbiology, pp. 62-75.

Loesche, W.J., Syed, S.A., Schmidt, E., and Morrison, E.C. (1985) Bacterial profiles of subgingival plaques in periodontitis. $J$ Periodontol 56: 447-456.

Ludwig, D.S., Holmes, R.K., and Schoolnik, G.K. (1985) Chemical and immunochemical studies on the receptor binding domain of cholera toxin B subunit. J Biol Chem 260: 12528-12534. 
Mäkinen, K.K., and Mäkinen, P.-L. (1987) Purification and properties of an extracellular collagenolytic protease produced by the human oral bacterium Bacillus cereus (strain Soc 67). J Biol Chem 262: 12488-12495.

Mäkinen, K.K., and Mäkinen, P.-L., Wilkes, S.H., Bayliss, M.E., and Prescott, J.M. (1982) Photochemical inactivation of Aeromonas aminopeptidase by 2,3-butanedione. J Biol Chem 257: 1765-1772.

Melchior, W.B., Jr, and Fahrney, D. (1970) Ethoxyformylation of proteins. Reaction of ethoxyformic anhydride with $\alpha$-chymotrypsin, pepsin, and pancreatic ribonuclease at $\mathrm{pH} 4$. Biochemistry 9: 251-258.

Miles, E.W. (1977) Modification of histidyl residues in proteins by diethylpyrocarbonate. Meth Enzymol 47: 431-442.

Neurath, H. (1984) Evolution of proteolytic enzymes. Science 224: 350-357.

Neurath, H. (1985) Proteolytic enzymes, past and present. Fed Proc 44: 2907-2913.

Neurath, H., Walsh, K.A., and Winter, W.P. (1967) Evolution of structure and function of proteases. Science 158: 1638-1644.

Ohta, K., Mäkinen, K.K., and Loesche, W.J. (1986) Purification and characterization of an enzyme produced by Treponema denticola capable of hydrolyzing synthetic trypsin substrates. Infect Immun 53: 213-220.

Phelps, D.C., and Hafeti, Y. (1984) Effects of $N, N^{\prime}$-dicyclohexylcarbodiimide and $\mathrm{N}$-(ethoxycarbonyl)-2-ethoxy-1,2-dihydroquinoline on hydride ion transfer and proton translocation activities of mitrochondrial nicotinamidenucleotide transhydrogenase. Biochemistry 23: 6340-6344.

Pougeois, R., Satre, M., and Vignais, P.V. (1978) N-Ethoxycarbonyl-2-ethoxy-1,2-dyhydroquinoline, a new inhibitor of the mitochondrial $F_{1}$-ATPase. Biochemistry 17: 3018-3023.

Saccomani, G., Barcellona, M.L., and Sachs, G. (1981) Reactivity of gastric $\left(\mathrm{H}^{+}+\mathrm{K}^{+}\right)$-ATPase to $\mathrm{N}$-ethoxycarbonyl-2-ethoxy1,2-dihydroquinoline. J Biol Chem 256: 12405-12410.

Ting, L.P., and Wang, J.H. (1980) Functional groups at the catalytic site of $F_{1}$ adenosine triphosphatase. Biochemistry 19: 5665-5670.

Whitaker, J.R., and Granum, P.E. (1980) An absolute method for protein determination based on differences in absorbance at 235 and 280nm. Analyt Biochem 109: 156-159. 
This document is a scanned copy of a printed document. No warranty is given about the accuracy of the copy. Users should refer to the original published version of the material. 